\title{
PERANCANGAN SISTEM KENDALI PADA ALAT LISTRIK RUMAH TANGGA MENGGUNAKAN MEDIA PESAN SINGKAT (SMS)
}

\author{
Hefmi Fauzan Imron, R. Rizal Isnanto*), Eko Didik Widianto**) \\ Program Studi Sistem Komputer, Fakultas Teknik, Universitas Diponegoro \\ Jalan Prof. Sudharto, Tembalang, Semarang, Indonesia
}

\begin{abstract}
Electricity is one of the important needs in life and for human dependency on electricity cause bad habits. Many people sometimes let an electrical appliance was left in light conditions that can cause waste and waste itself is not the only issue that will arise, but also can cause a fire. Therefore, research must be done to develop a system that can control and know the status of power tools that can be accessed remotely, for example via short messages service (SMS).The test result show the system can turn on and off the terminal that is connected to the power tool using the command short message services (SMS), the system is able to detect the presence of human body heat, the system is able to check the state of the terminal in a position on or off, the system is able to give notification via short message services (SMS) on the use of electrical components is neglected and if there are foreigners who wish to enter into the system.
\end{abstract}

Keywords: Electrical Equipment Control, Short Message Service (SMS), Arduino, Electric Current and Relay

\section{PENDAHULUAN}

Listrik merupakan hal yang sangat penting di kehidupan kita. Setiap pekerjaan kita pasti dibantu dengan adanya listrik. Mulai dari penerangan hingga pengaturan suhu ruangan pun semuanya dibantu oleh listrik.

Ketergantungan manusia terhadap listrik ini menimbulkan kebiasaan buruk. Banyak orang yang terkadang membiarkan suatu perangkat hidup baik saat ada di rumah ataupun saat tidak di rumah (pergi jauh). Contohnya adalah lupa mematikan semua lampu atau lupa mematikan TV dan bahkan lupa apakah kondisi listrik di rumah sudah mati atau belom saat ditinggal bepergian jauh seperti Mudik Lebaran, dan lain-lain. Hal ini tentu saja mengakibatkan pemborosan listrik yang sangat besar walaupun menggunakan alat yang hemat energi sekalipun $^{[6]}$.

Penelitian telah banyak dilakukan untuk dapat melakukan pengontrolan alat listrik dengan baik dan efektif. Namun pada dasarnya penelitian yang dilakukan hanya sekedar mematikan dan menyalakan peralatan listrik saja, tidak terdapat fitur lain

Pembuatan sistem kendali untuk mengontrol peralatan listrik juga dilakukan oleh Nanang Sutarmanto (2007) ${ }^{[7]}$, namun sekali lagi sistem yg dibuat hanya sekedar mematikan dan menyalakan peralatan listrik dari jauh menggunakan pesan singkat (SMS)

*) R. Rizal Isnanto

Email : rizal_isnanto@undip.ac.id

*) Eko Didik Widianto

Email : didik@live.undip.ac.id
Dari beberapa pemaparan diatas maka muncul ide pada penelitian ini untuk membuat sistem dengan maksud menyempurnakan dan menambahkan beberapa fitur yang tidak ada dari penelitian sebelumnya. Sistem yang dibuat pada penelitian ini memiliki perbedaan dibanding penelitian sebelumnya, yaitu penambahan sensor arus untuk mencari arus instan dan sensor PIR untuk mendeteksi keberadaan manusia, yang keduanya bisa di implementasikan dalam sistem yang akan dibuat dan terdapat juga penambahan beberapa fitur seperti mode hemat dan mode aman dalam implementasinya.

\section{METODOLOGI PENELITIAN}

Dalam pembuatan sistem kendali pada alat listrik rumah tangga menggunakan media pesan singkat (SMS), metode yang digunakan adalah model waterfall, dimana pekerjaan dilakukan secara bertahap ${ }^{[5]}$, Terdapat 5 tahapan yaitu penentuan konsep, spesifikasi kebutuhan, desain dan perancangan sistem, implementasi perangkat keras dan lunak dan tahap terakhir yaitu pengujian.

Pada tahap konsep perlu menentukan tujuan termasuk spesifikasi kebutuhan. Pembuatan sistem ini bertujuan untuk membuat sebuah sistem yang bisa mengontrol dan melihat status kelistrikan dalam rumah. Selain itu, sistem yang akan dibuat juga harus mudah digunakan oleh pengguna, dimana media pesan singkat (SMS) yang jadi protokol untuk menyalakan, mematikan dan melihat status kelistrikan. Pesan singkat (SMS) sendiri merupakan hal yang tidak asing lagi bagi pengguna, karena layanan pesan singkat bisa ditemukan di ponsel pintar manapun, bahkan sebelum era ponsel pintar pun, layanan pesan singkat (SMS) ini sudah terlebih dahulu ada.

Tahap spesifikasi kebutuhan merupakan tahap untuk melakukan analisa dan menjabarkan kebutuhan yang diperlukan dalam melakukan penelitian. Developer mengumpulkan data yang dibutuhkan untuk penelitian dengan mencoba menganalisa dan membandingkan beberapa sistem kendali jarak jauh yang sudah ada, mencari data tentang cara pengembangan sistem kendali jarak jauh melalui pesan singkat $(\mathrm{SMS})^{[1]}$. Selanjutnya developer melakukan pengumpulan peralatan untuk membuat sebuah sistem seperti Relay, Modul ACS712, SIM900 Mini Modul dan juga Sensor PIR, sehingga dapat membangun sistem kontrol kendali alat listrik menggunakan media pesan singkat (SMS). Ada beberapa spesifikasi yang harus dipenuhi untuk menerapkan sistem kontrol kendali alat listrik menggunakan media pesan singkat (SMS), baik segi 
teknis maupun pengguna. Dalam hal ini format pesan singkat (SMS) untuk mengendalikan alat listrik harus benar benar valid. Karena di dalam sistem ini perintah untuk mengendalikan peralatan listrik harus melalui format SMS yang benar dan tentunya dikirim ke nomor SIM900 Mini Modul yang terhubung dengan sistem pengendali peralatan listrik.

Tahap desain dan perancangan sistem harus segera dibuat setelah tahap konsep dan spesifikasi kebutuhan sudah terpenuhi. Tahap desain dan perancangan sistem dibuat berdasarkan peralatan apa saja yang digunakan untuk mewujudkan sebuah sistem pengendali peralatan listrik $^{[2]}$. Perancangan dan desain yang cepat berfokus pada penggambaran aspek aspek sistem yang nantinya di akses oleh pengguna dan proses pengiriman SMS sebagai kendali peralatan listrik melalui beberapa tahap, yaitu :

1. Pengguna mengirimkan format SMS berupa teks ke sistem

2. SMS yang masuk ke sistem akan dibaca dan diverifikasi dan bila format benar, maka sistem akan melakukan kegiatan berdasarkan perintah dari pengguna

3. Setelah aktifitas berhasil dijalankan (menyalakan, mematikan dan mengetahui status alat listrik) maka sistem akan memberikan laporan sesuai dengan perintah yang dijalankan dengan mengirimkan SMS laporan kepada pengguna

Tahapan selanjutnya yaitu implementasi perangkat keras dan perangkat lunak, pada implementasi perangkat keras, dari peralatan yang sudah dirancang kemudian diimplementasikan menjadi sebuah rangkatan sistem yang nantinya bisa mengontrol peralatan listrik dan setelah implementasi perangkat keras selesai dibuat, selanjutnya yaitu tahap implementasi perangkat lunak tujuannya untuk membentuk sebuah sistem dengan memberikan senarai maupun fungsi yang kemudian menjadi perintah perintah internal dalam sebuah sistem, sehingga sistem dapat mengolah data input dari pesan yang dikirim menjadi data output yang diimplementasikan pada perangkat listrik dan pesan yang menjadi protokol bisa mengeksekusi peralatan listrik sesuai dengan pesan yang dikirim oleh pengguna.

Tahap terakhir yaitu tahap pengujian, tahap ini dilakukan setelah semua tahapan sebelumnya sudah selesai dilakukan. Pengujian mutlak dibutuhkan agar sistem tidak hanya menjadi program abstrak yang tidak dapat berjalan pada saat penggunaan sistem ${ }^{[3]}$. Pengujian dilakukan untuk menunjukkan apakah keseluruhan sistem telah dapat bekerja sesuai dengan yang diinginkan. Berikut pengujian yang dilakukan dan akan di bahas dalam bab pengujian :

1. Pengujian kerja sistem

2. Pengujian mode sistem

3. Pengujian deteksi menggunakan sensor PIR

4. Pengujian sensor arus ACS712

5. Pengujian menyalakan dan mematikan terminal

6. Pengujian respon pesan singkat (SMS) terhadap sistem

7. Pengujian perintah di luar sistem

8. Pengujian Identifikasi Nomor Telepon

\section{PERANCANGAN SISTEM}

Pada bagian ini akan dijabarkan mengenai kebutuhan dan metode yang digunakan untuk merancang perangkat keras dan perangkat lunak sistem. Perancangan diperlukan untuk memberikan metode dan tahapan yang jelas untuk membuat sistem sesuai dengan tujuan yang telah ditentukan.

\section{Identifikasi Kebutuhan Sistem}

Proses ini dibutuhkan untuk melakukan proses identifikasi dan proses analisa kebutuhan-kebutuhan yang diperlukan untuk membuat sistem. Kebutuhan-kebutuhan tersebut terdiri atas kebutuhan fungsional dan nonfungsional, yang dijelaskan sebagai berikut.

a. Kebutuhan Fungsional

Kebutuhan fungsional dalam perancangan sistem adalah sebagai berikut:

1. Alat menggunakan mikrokontroller sebagai pusat kontrol untuk mengetahui kondisi alat-alat listrik.

2. Alat dapat membaca dan menerima pesan singkat (SMS) untuk digunakan sebagai parameter dalam perintah untuk menyalakan maupun mematikan alatalat listrik

3. Alat ini tidak akan bekerja apabila listrik padam, dan kondisi apabila listrik padam akan mati semua.

4. Alat ini hanya akan memberi notifikasi kepada nomer yang sudah diinisialisasikan kepada mikrokontroller.

5. Pada sistem terdapat mode manual, mode hemat dan mode aman yang bisa diaktikan pengguna menggunakan media pesan singkat (SMS).

6. Semua alat alat listrik bisa dikontrol dengan alat ini, tapi dalam Tugas Akhir ini, alat yang dipilih merupakan alat alat listrik yang lebih berpotensi dilalaikan.

b. Kebutuhan Non-Fungsional

Kebutuhan non-fungsional perancangan sistem adalah sebagai berikut:

1. Purwarupa sistem dibuat sedemikian rupa sehingga memudahkan dalam proses pemasangan dan penggunaannya.

2. Konstruksi purwarupa alat dibuat berdasarkan rumah dari pengguna, karena denah rumah setiap pengguna berbeda-beda

3. Miniatur sistem ini terbuat dari kayu sehingga memudahkan dalam pemasangannya

2. Perancangan dan Implementasi Perangkat Keras

Proses perancangan perangkat keras akan menjabarkan rancangan perangkat keras yang akan digunakan untuk membuat sistem, mulai dari perangkat keras utama yang dibutuhkan sistem hingga instrumen-instrumen elektronika pendukungnya $^{[4]}$. Pada Gambar 1 ditunjukkan diagram blok perangkat keras sistem, yang menunjukkan rancangan perangkat keras sistem yang akan dibuat. 


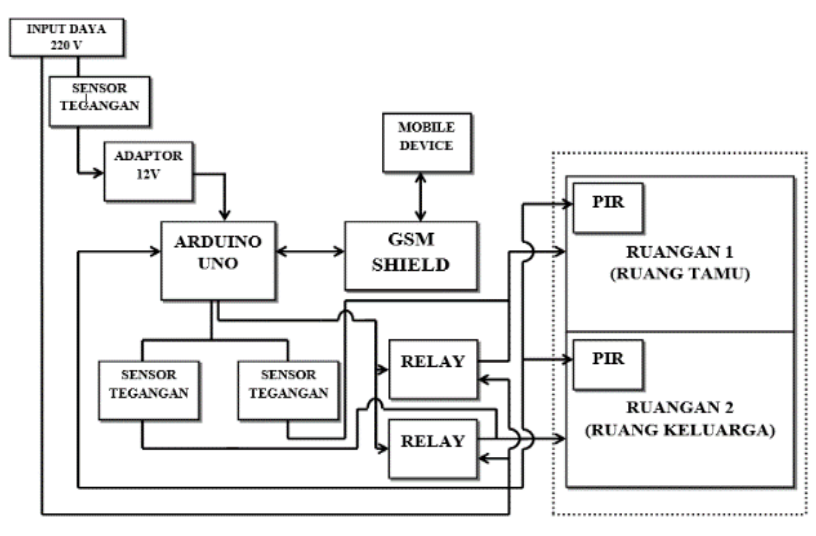

Gambar 1 Diagram blok perangkat keras sistem

Pusat pengendalian sistem menggunakan arduino mega 2560 (Arduino Mega) ${ }^{[8]}$. Komponen yang terhubung di sistem diantaranya yaitu, Relay sebagai saklar yang terhubung dengan terminal, 2 buah terminal di masing masing ruangan a dan ruangan $b$ yang terhubung langsung dengan perangkat yang akan dikontrol, SIM900 Mini Modul sebagai penerima pesan singkat (SMS) yang dikirim dari pengguna, sensor arus ACS712 dan sensor PIR untuk mendeteksi panas tubuh manusia. Tabel 1 menunjukkan antarmuka pin arduino dengan komponen yang lain.

Tabel 1 Antarmuka pin komponen dengan Arduino

\begin{tabular}{|c|c|c|}
\hline Komponen & Pin Arduino & Pin Komponen \\
\hline Sensor PIR a & Out & 2 \\
\hline Sensor PIR b & Out & 3 \\
\hline \multirow{2}{*}{ Relay a } & IN1 & 4 \\
IN2 & 5 \\
\hline \multirow{2}{*}{ Relay b } & IN1 & 6 \\
& IN2 & 7 \\
\hline \multirow{2}{*}{ SIM900 Mini Modul } & 0 (RX) & 8 \\
\hline Modul ACS712 a & Out & A0 \\
\hline Modul ACS712 b & Out & A1 \\
\hline Modul ACS712 c & Out & Semua Vcc \\
\hline Semua Pin Vcc Komponen & Vcc & \multirow{2}{*}{ Semua GND } \\
\hline Semua Pin GND & GND & \\
Komponen & &
\end{tabular}

3. Perancangan dan Implementasi Program

Proses perancangan perangkat lunak akan menjelaskan tahapan dalam pembuatan program yang mengendalikan perangkat keras. Perilaku sistem akan ditentukan oleh perangkat lunak yang tertanam didalamnya ${ }^{[4]}$ dan menjadi otak yang mengontrol dan mengetahui status alat listrik. Sistem harus mampu menerima pesan singkat (SMS) untuk mengontrol peralatan alat listrik yang berdasarkan dalam ruangan.

Pesan singkat (SMS) sebagai media pengontrol bisa melakukan beberapa perintah yakni mengganti mode pada sistem (mode aman dan mode hemat), mematikan sekaligus menyalakan terminal yang terhubung dengan alat alat listrik, mengecek arus yang berjalan dalam peralatan listrik yang sedang digunakan beserta notifikasi dan juga terdapat sensor PIR yang mendeteksi keberadaan manusia untuk memberi informasi kepada pengguna melalui pesan singkat (SMS) bahwa alat listrik digunakan dalam ruangan tersebut dalam kondisi ditinggal atau tidak (ada pengguna yang terdeteksi dalam ruangan tersebut)

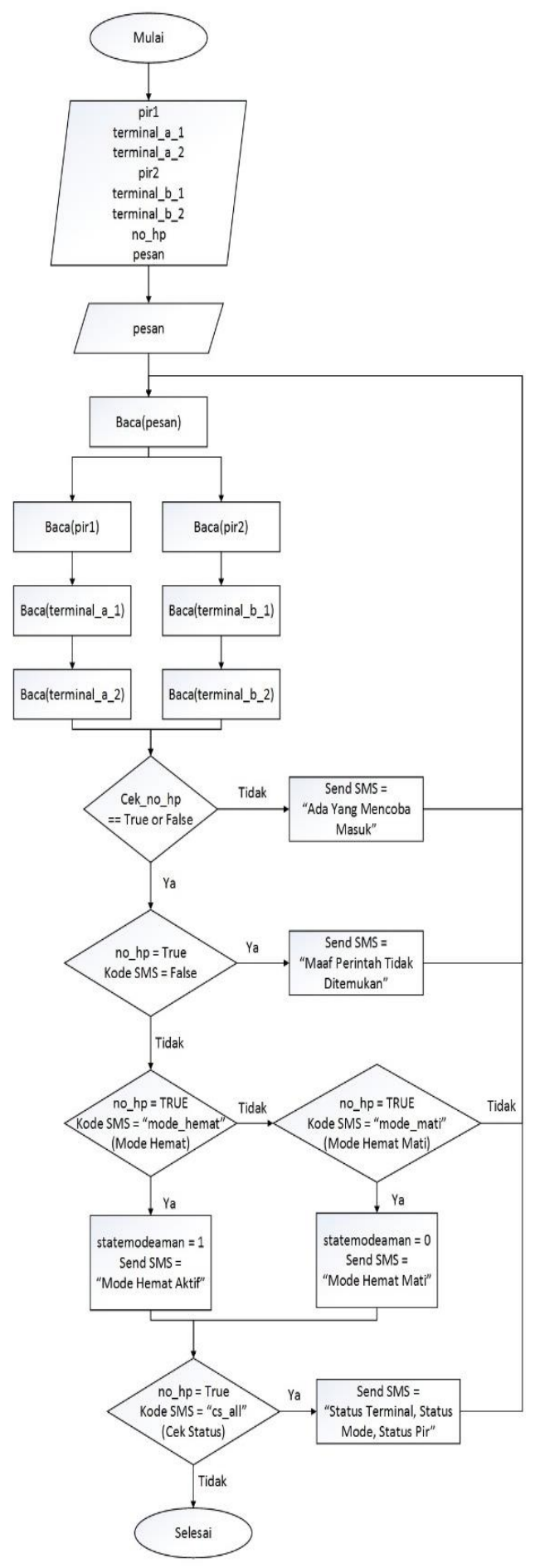

Gambar 2 Diagram alir mode hemat

Mode hemat bisa disebut juga mode otomatis pada sistem, karena mode ini sistem membaca apakah terdeteksi tubuh manusia atau tidak, setelah sebuah kondisi terpenuhi, aksi sistem selanjutnya yaitu terminal pada ruangan a ataupun $b$ akan menyala jika terdeteksi pengguna di salah satu ruangan baik ruangan a ataupun ruangan $b$. Pada mode hemat sensor PIR berperan penting dalam mengontrol terminal yang terhubung dengan alat listrik, ketika pengguna mengirim perintah "mode_hemat" ke sistem, status mode menjadi statemodehemat $=1$ (mode aktif), kemudian sistem akan merubah mode menjadi mode 
hemat, dimana ketika PIR bernilai 1 (HIGH) semua terminal pada ruangan a dan $\mathrm{b}$ akan menyala, dan ketika PIR bernilai $0(L O W)$ terminal akan mati dengan otomatis dijelaskan oleh diagram alir pada Gambar 2.

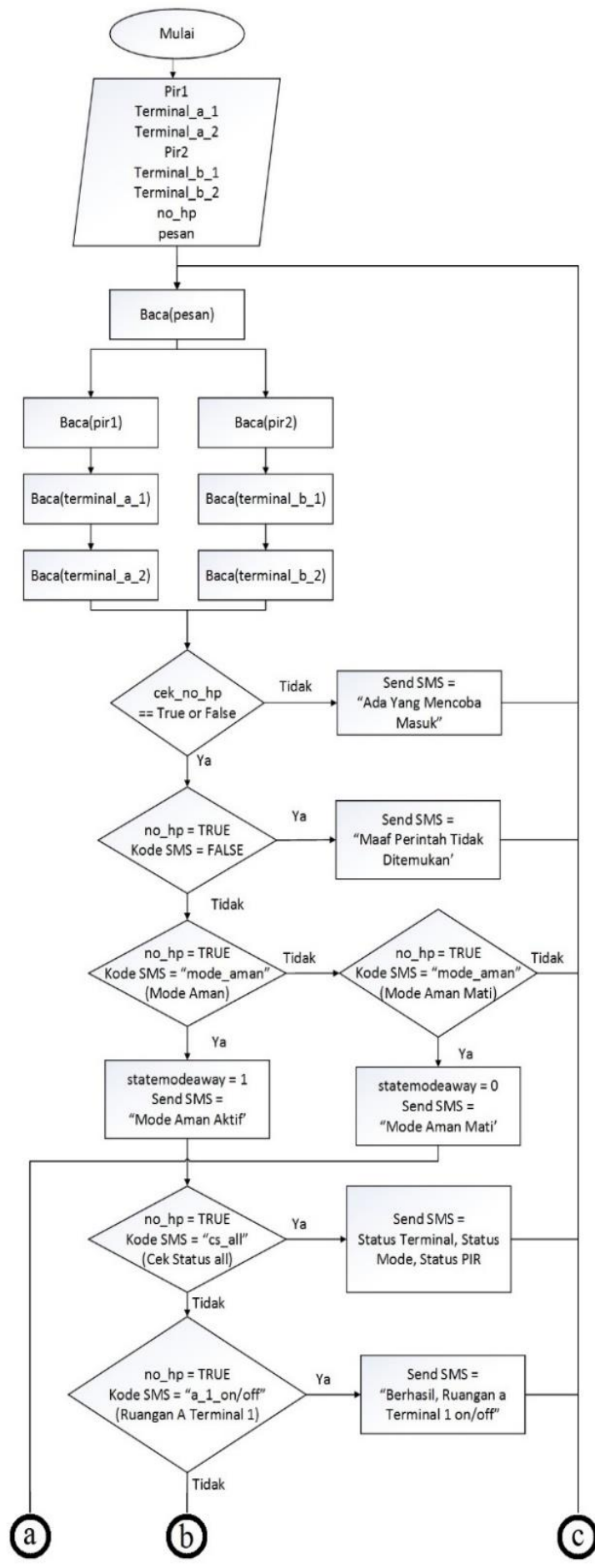

Gambar 3 Diagram alir mode aman.

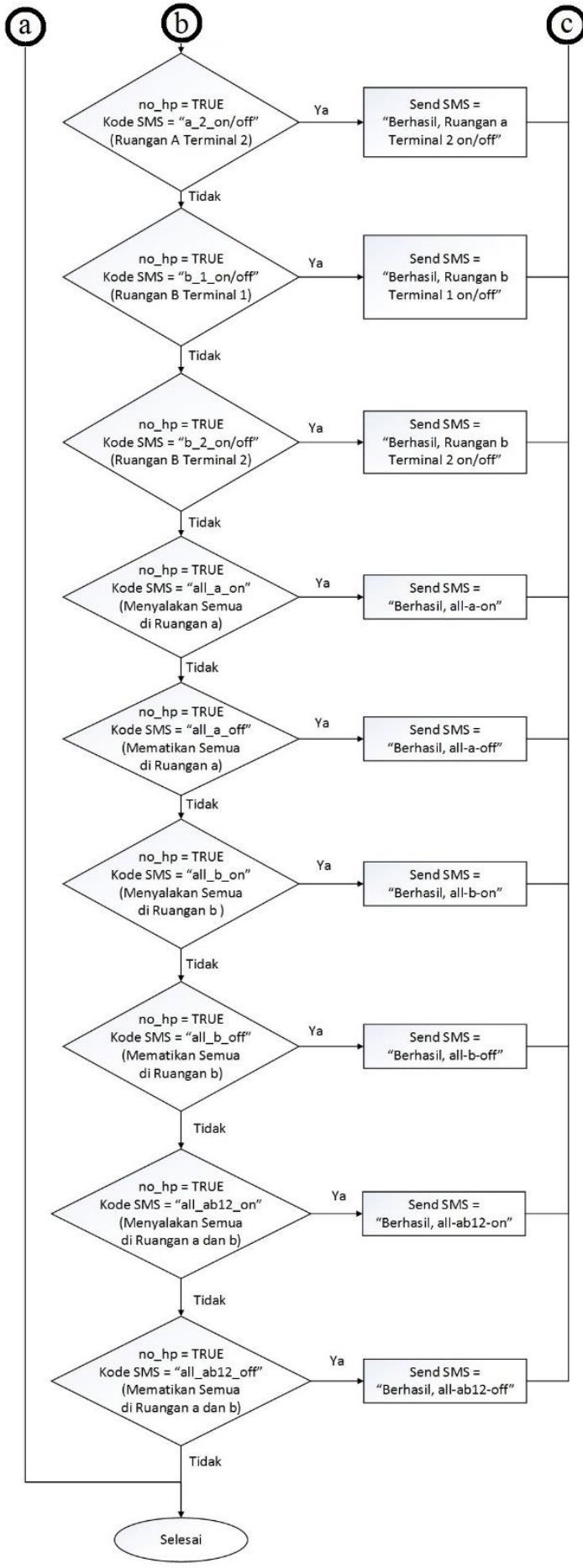

Gambar 4 Diagram alir mode aman (lanjutan)

Pada Gambar 3 dan 4 ditunjukkan diagram alir pada mode aman dan mode ini efektif digunakan ketika pengguna dalam kondisi tidak di rumah atau sedang pergi jauh, pada mode ini pengguna tetap bisa menyalakan dan mematikan terminal menggunakan pesan singkat (SMS), namun peran sensor PIR di sini yaitu untuk membaca apakah saat kondisi rumah ditinggal, ada orang lain yang tidak diinginkan mengunjungi rumah dari pengguna tersebut dan sistem akan memberikan notifikasi ke pengguna bahwa ada orang yang terdeteksi jika suatu kondisi dalam sistem terpenuhi. 
Ketika sebuah kondisi terpenuhi, sistem akan mengirimkan notifikasi ke pengguna melalui pesan singkat. Isi pesan singkat tersebut yaitu, memberitahukan user bahwa sistem telah mendeteksi kehadiran orang yang tidak diinginkan, dalam mode ini perilaku sistem memiliki 2 kondisi yang harus terpenuhi untuk mengirimkan notifikasi, yaitu jika kondisi sensor PIR bernilai 1 (HIGH), dan kondisi pada sensor arus $=0,10 \mathrm{~A}$ (tidak ada terminal yang aktif), sistem akan mengirimkan notifikasi dengan tujuan memberitahukan pengguna bahwa ada seseorang yang terdeteksi oleh sensor PIR dan lampu yang ada pada salah satu ruangan akan menyala sebagai bentuk tindakan pencegahan atas kejadian yang tidak diinginkan, selanjutnya kondisi ke 2 yaitu jika kondisi sensor PIR bernilai 1 (HIGH) dan kondisi pada sensor arus yakni >= 0,10 A (ada salah satu terminal yang aktif atau semua semua terminal aktif), sistem akan mengirimkan notifikasi saja dengan tujuan yang masih sama dengan kondisi yang pertama.

Isi dari notifikasi tersebut selain pemberitahuan tentang kondisi sensor PIR, ada juga perintah untuk mematikan lampu yang menyala sesuai terminal pada ruangan a ataupun b (kondisi ke 1) dan juga terdapat perintah notif mati. Perintah ini bertujuan untuk apabila notifikasi tersebut dirasa mengganggu pengguna, dikarenakan terjadi kesalahan pembacaan pada sensor. Jika pengguna ingin notifikasi tersebut kembali aktif, pengguna bisa mengirimkan perintah dengan format notif_hidup, dengan ini sistem akan aktif kembali seperti semula untuk mengirimkan notifikasi jika sebuah kondisi terpenuhi. Selain itu pengguna juga bisa langsung dapat mengecek langsung dengan format perintah Cs all (cek status) dan juga perintah ca_all (cek arus)

Perintah cs_all dan ca_all akan menunjukkan status dari terminal_a_1, terminal_a_2, terminal_b_1, terminal_b_2, mode yang digunakan dan juga status arus dari masing masing terminal, arti dari terminal a 1 yaitu terminal 1 di ruangan $\mathrm{A}$, jadi jika terminal dalam kondisi menyala dan sensor PIR mendeteksi sesuatu, pengguna sendiri dapat memutuskan apakah kondisi terminal akan tetap menyala ataupun dimatikan dengan perintah yang sudah dibuat di dalam sistem dan sebaliknya jika terminal dalam kondisi menyala tetapi sensor PIR tidak mendeteksi, pengguna yang bisa memutuskan apakah tetap dinyalakan atau tidak.

Agar sistem bisa menyalakan dan mematikan terminal yang terhubung dengan alat listrik dengan menggunakan pesan singkat (SMS) maka terdapat beberapa format perintah yang ada dan sudah di simpan dalam sistem. Kemudian setelah sistem melakukan pengecekan awal dari beberapa variabel yang berhubungan pada sistem seperti pir1, pir2, terminal_a_1, terminal_a_2, terminal_b_1, terminal_b_2 dan no_hp akan membaca informasi dari sms yang dikirimkan oleh pengguna dengan inisialisasi cek no hp dan berisikan perintah, contohnya perintah Cs_ali (C) (Cek Status), yang kemudian sistem akan melakukan inisialisasi nomor hp pengguna dan mengirimkan informasi dari data "cs_all" menuju ke pengguna via pesan singkat (SMS). Pada Tabel 2 menunjukkan secara garis besar tentang perintah apa saja yang akan digunakan.

Tabel 2 Perintah pesan singkat (SMS) dalam sistem.

\begin{tabular}{|c|c|c|}
\hline No & Perintah & Keterangan \\
\hline 1. & cs_all & $\begin{array}{l}\text { Untuk mengecek status dari terminal, } \\
\text { sensor PIR dan status mode }\end{array}$ \\
\hline 2. & ca_all & $\begin{array}{l}\text { Untuk mengecek kondisi sensor arus dan } \\
\text { sensor PIR }\end{array}$ \\
\hline 3. & a_1_on & $\begin{array}{l}\text { Untuk menyalakan terminal } 1 \text { pada } \\
\text { ruangan a }\end{array}$ \\
\hline 4. & a_1_off & $\begin{array}{l}\text { Untuk mematikan terminal } 1 \text { pada } \\
\text { ruangan a }\end{array}$ \\
\hline 5 . & a_2_on & $\begin{array}{l}\text { Untuk menyalakan terminal } 2 \text { pada } \\
\text { ruangan a }\end{array}$ \\
\hline 6. & a_z ${ }^{2}$ off & $\begin{array}{l}\begin{array}{l}\text { Untuk mematikan } \\
\text { ruangan a }\end{array} \\
\text { ruminal } 2 \text { pada } \\
\end{array}$ \\
\hline 7. & b_1_on & $\begin{array}{l}\text { Untuk menyalakan terminal } 1 \text { pada } \\
\text { ruangan b }\end{array}$ \\
\hline 8. & b_1_off & $\begin{array}{l}\text { Untuk mematikan terminal } 1 \text { pada } \\
\text { ruangan b }\end{array}$ \\
\hline 9. & b_2_on & $\begin{array}{l}\text { Untuk menyalakan terminal } 2 \text { pada } \\
\text { ruangan b }\end{array}$ \\
\hline 10. & b_ ${ }^{2}$ _off & $\begin{array}{l}\text { Untuk mematikan terminal } 2 \text { pada } \\
\text { ruangan b }\end{array}$ \\
\hline 11. & all_a_on & $\begin{array}{l}\text { Menyalakan semua terminal pada } \\
\text { ruangan a }\end{array}$ \\
\hline 12. & all_a_off & $\begin{array}{l}\text { Mematikan semua terminal pada } \\
\text { ruangan a }\end{array}$ \\
\hline 13. & all_b_on & $\begin{array}{l}\text { Menyalakan semua terminal pada } \\
\text { ruangan b }\end{array}$ \\
\hline 14. & all_b_off & $\begin{array}{l}\text { Mematikan semua terminal pada } \\
\text { ruangan b }\end{array}$ \\
\hline 15. & all_ab12_on & $\begin{array}{l}\text { Menyalakan semua terminal } \\
\text { ruangan a dan b }\end{array}$ \\
\hline 16. & all_ab12_off & $\begin{array}{l}\text { Mematikan semua terminal } \\
\text { ruangan a dan } b\end{array}$ \\
\hline
\end{tabular}

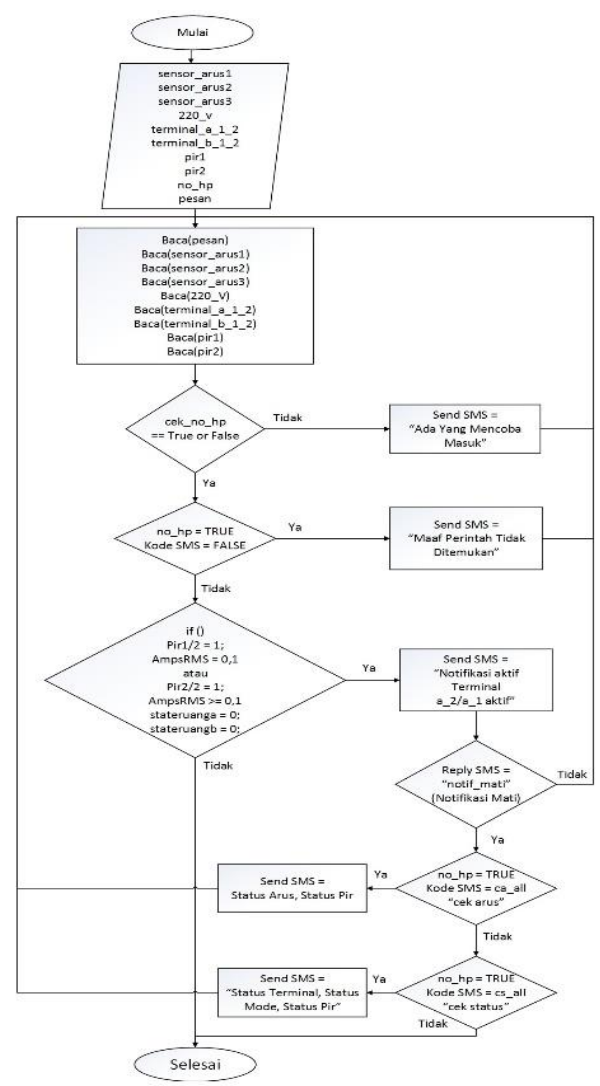

Gambar 5 Bagan alir kerja sistem yang berinteraksi dengan sensor arus dan sensor PIR (mode aman) 
Selain berhubungan dengan sensor PIR, sistem juga terhubung dengan sensor arus Modul ACS712, ketika terminal dalam keadaan menyala maka Modul ACS712 akan bisa membaca arus yang sedang berjalan di terminal tersebut (instant current), dalam sistem ini pengguna juga bisa mengecek arus yang sedang berjalan (digunakan) melalui pesan singkat (SMS) dan juga sistem akan memberi notifikasi ketika dalam mode aman,

Format perintah sudah diinisialisasi dalam sistem dan juga terdapat beberapa variabel yang berhubungan dalam sistem ini yaitu sensor_arus1, sensor_arus2, sensor_arus3, terminal_a_1_2, terminal_b_1_2 dan $220 \mathrm{v}$ juga akan membaca informasi dari sms yang dikirimkan oleh pengguna dengan inisialisasi cek_no_hp dan berisikan perintah yakni "ca_all" (cek arus) yang kemudian sistem akan melakukan inisialisasi nomor hp pengguna dan mengirimkan informasi dari data "ca_all" menuju ke pengguna via pesan singkat (SMS). Pada Gambar 5 merupakan bagan alir kerja sistem yang berinteraksi dengan sensor arus dan sensor PIR dalam mode aman.

\section{Perancangan Pengujian}

Pengujian diperlukan untuk membuktikan bahwa sistem mampu bekerja sesuai dengan tujuan yang diinginkan dan mampu memberikan perilaku sesuai dengan rancangan yang telah dibuat sebelumnya. Sistem diletakkan pada purwarupa kayu berukuran panjang $\mathrm{x}$ lebar $\mathrm{x}$ tinggi sebesar $30 \times 60 \times 30 \mathrm{~cm}$ yang memiliki 2 ruangan yang terpasang masing masing 2 buah terminal. Pada Gambar 6 dan Gambar 7 menunjukkan purwarupa yang terbuat dari kayu yang telah terpasang komponen. Pengujian akan dilakukan dalam berbagai bentuk untuk menguji keberhasilan sistem.
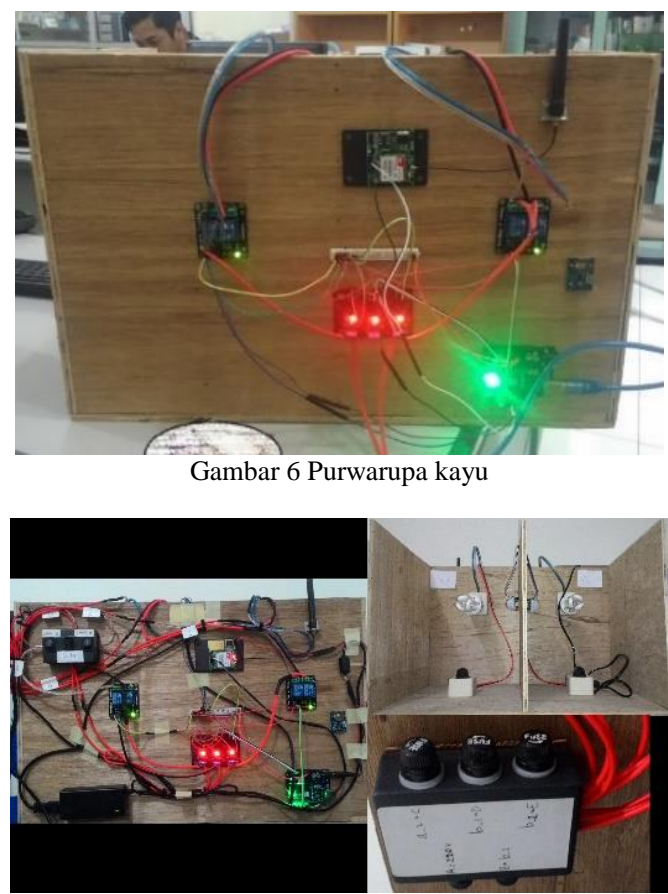

Gambar 7 Purwarupa kayu

\section{IV.PENGUJIAN DAN ANALISIS}

Pengujian dan analisis ini akan menjelaskan tentang pengujian sistem, apakah fungsi-fungsi pada sistem telah berjalan dengan baik atau tidak. Sistem diuji apakah sesuai dengan perancangan yang dilakukan di bab sebelumnya.

\section{Pengujian Unit}

Pengujian unit menunjukkan apakah sistem sudah memiliki perangkat keras yang dibutuhkan untuk menjalankan sistem. Pengujian ada atau tidaknya asap, pengujian koneksi komponen dengan papan mikrokontroler dan pengujian tegangan yang diterima oleh komponen. Sistem membutuhkan tegangan masukan DC 12 Volt. Berikut pada Gambar 8 menunjukkan ketika sistem menyala dengan menggunakan tegangan yang berasal adaptor 12 Volt

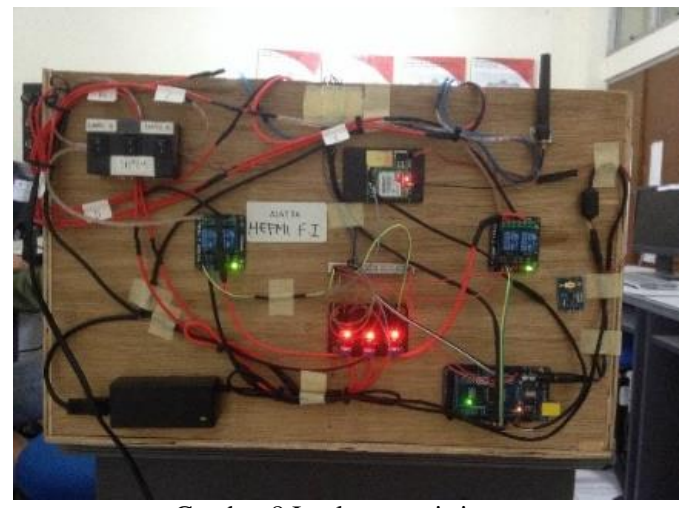

Gambar 8 Implementasi sistem

\section{Pengujian Kerja Sistem}

Pengujian kerja sistem dilakukan untuk menunjukkan apakah keseluruhan sistem telah dapat bekerja sesuai dengan yang diinginkan. Pengujian ini telah dirancang sebelumnya, pengujian ini terdiri atas pengujian terhadap fungsi-fungsi dari sistem.

Dari hasil pengujian yang telah dilakukan, sistem mampu berinteraksi dengan baik dilihat dari hasil pengujian yang sepenuhnya berhasil diuji yaitu saat awal sistem dinyalakan terminal dalam keadaan mati dalam mode manual kemudian sistem mengirimkan notifikasi ke pengguna tentang penggunaan mode, Sensor Pir beserta sensor arus dapat mendeteksi dengan baik, sistem mampu merespon sesuai perintah yang dikirim, sistem bisa mematikan dan menyalakan notifikasi pada "mode aman" dan pesan singkat (SMS) tidak akan berfungsi ketika sistem dalam keadaan mati.

Selanjutnya, pengujian ini dilakukan untuk membuktikan bahwa sistem mampu menerima pesan yang dikirim oleh pengguna dan sistem juga mampu membalas pesan kembali ke pengguna sesuai dengan isi pesan yang dikirim oleh pengguna tersebut.

Pengujian yang dilakukan berhasil dan menunjukkan bahwa ketika beberapa perintah yang dikirim oleh pengguna dan diterima oleh sistem (pesan yang dikirim harus sesuai dengan format). Sistem mampu merespon dengan membalas pesan singkat yang dikirim oleh 
pengguna, dan perilaku sistem akan sesuai dengan perintah yang dikirim oleh pengguna.

\section{Pengujian Mode Sistem (mode_hemat, mode_aman)}

a. Mode Sistem $=$ mode hemat

Pengujian ini dilakukan apakah sistem mampu merespon ketika pengguna mengirim pesan ke sistem dengan perintah "mode_hemat" dan juga sistem akan merespon sesuai dengan mode yang digunakan yaitu ketika sensor PIRa dan PIRb mendeteksi adanya pengguna di ruangan tersebut maka terminal pada ruangan a dan terminal pada ruangan $b$ akan menyala secara otomatis, dan ketika PIRa dan PIRb tidak mendeteksi, maka terminal akan otomatis mati.

Hasil pengujian menunjukkan "mode hemat" berhasil di eksekusi yaitu ketika pengguna mengirim pesan singkat (SMS) ke sistem dengan perintah "mode_hemat", maka sistem akan membalas dengan isi pesan "Mode Aman Aktif" dan perilaku sistem akan sesuai dengan perancangan yang telah dibuat.

\section{b. Mode Sistem = mode aman}

Pengujian ini dilakukan apakah sistem mampu merespon ketika pengguna mengirim pesan ke sistem dengan perintah "mode_aman" dan juga sistem mampu mengirimkan notifikasi kepada pengguna ketika kondisi yang dibutuhkan dalam sistem terpenuhi. Terdapat 2 perintah untuk menyalakan dan mematikan notifikasi dan dalam pengujian ini 2 perintah tersebut juga akan diuji dari awal ketika pengguna mengaktifkan "mode aman" melalui pesan singkat (SMS).

Hasil pengujian menunjukkan "mode_aman" berhasil di eksekusi yaitu ketika pengguna mengirim pesan singkat (SMS) ke sistem dengan perintah "mode aman", sistem akan membalas dengan isi pesan "Mode Aman Aktif", dan perilaku sistem akan berubah sesuai dengan perancangan yang telah dibuat, kemudian untuk 2 perintah menyalakan dan mematikan notifikasi yaitu notif hidup dan notif mati berhasil diuji dengan baik, yaitu ketika notif hidup, sistem akan mengirimkan notifikasi ke pengguna tetapi ketika pengguna ingin mematikan notifikasi dari sistem, perintah notif mati dikirim ke sistem, sistem merespon bahwa perintah tersebut berhasil diaktifkan dan notifikasi akan mati (tidak ada notifikasi lagi dari sistem).

\section{Pengujian Deteksi Menggunakan Sensor PIR}

Pada tahap ini sensor PIR akan diuji apakah saat sistem berjalan mampu membaca semua kondisi yang mungkin ketika pengguna mengirimkan beberapa format perintah untuk menyalakan dan mematikan terminal dan sistem juga harus bisa membaca keberadaan panas tubuh manusia (mendeteksi manusia) baik di ruangan a dan ruangan $b$ berikut adalah kemungkinan yang akan diterima sistem.

Hasil pengujian deteksi sensor PIR berhasil yaitu, sistem mampu membaca beberapa kondisi yang memungkinkan pada ke dua buah ruangan sesuai dengan parameter yang telah dibuat saat sistem aktif, dan juga sistem mampu membaca kondisi terminal menyala ataupun mati.

\section{Pengujian Sensor Arus ACS712}

Pengujian ini dilakukan untuk mengetahui apakah sensor arus dapat mendeteksi arus yang terdapat pada ruangan a dan ruangan $b$. Terminal pada ruangan a dan ruangan $b$ tersambung dengan relay dan kabel tembaga dari relay terhubung dengan modul ACS712 yang disambungkan dengan IP+ dan IP-, selanjutnya arus yang mengalir melalui IP+ dan IP- akan terbaca dan ditangkap oleh sistem. Pengujian akan dilakukan ketika kondisi awal sistem dijalankan dan ketika salah satu atau semua terminal dinyalakan.

Hasil pengujian dari pembacaan arus dari penggunaan terminal pada ruangan a dan ruangan $\mathrm{b}$ berhasil dilakukan, yaitu arus saat terminal menyala ataupun mati (dengan kondisi terhubung dengan alat listrik) sensor arus mampu menampilkan nilai dari penggunaan arus yang sesuai dengan parameter yang diuji dengan satuan Ampere/s RMS, tetapi ketika terminal dalam kondisi tidak ada arus, sensor arus tidak membaca dalam kondisi $0 \mathrm{~A}$, sensor akan memberikan nilai 0,10 A karena pembacaan modul ACS712 tidak linear pembacaannya ketika dalam kondisi 0 A, tetapi ketika modul ACS712 mendeteksi arus diatas 0,25 A, maka pembacaannya akan kembali normal untuk membaca instant current (arus instan).

\section{Pengujian Menyalakan dan Mematikan Terminal}

Pengujian ini dilakukan untuk mengetahui apakah terminal dapat dimatikan dan dinyalakan menggunakan pesan singkat (SMS) dengan baik sesuai perancangan. Terminal pada sistem terhubung dengan relay, maka relay ini yang akan dikontrol oleh Arduino untuk memutuskan ataupun menyalakan terminal, ketika sistem menerima perintah untuk mematikan dan menyalakan sistem harus mampu mematikan terminal dan menyalakan terminal sesuai dengan perintah yang dikirim oleh pengguna.

Hasil pengujian yang telah dilakukan yaitu ketika nilai sensor PIR $=1(\mathrm{HIGH})$ terminal akan menyala dan ketika 0 (LOW) terminal akan mati. Pada modul relay juga dapat menunjukkan sebuah kondisi, yaitu terdapat led warna merah pada modul relay, ketika led tersebut menyala kondisi terminal akan mati dan ketika led tersebut dalam kondisi mati maka kondisi terminal akan menyala.

\section{Pengujian Respon Pesan Singkat Terhadap Sistem}

Pada tahap pengujian ini lamanya waktu respon sistem ketika menerima pesan dari pengguna akan diuji dalam beberapa kali percobaan, selanjutnya setelah menerima pesan dari pengguna, sistem mampu merespon dengan baik setelah diberi perintah dari pengguna dan membalas pesan ke pengguna. Pengujian akan menggunakan purwarupa langsung dengan melihat lamanya waktu respon alat ketika menerima pesan dan membalas pesan dengan menggunakan penghitung waktu. Pengujian dilakukan di Laboraterium Sistem Embedded dan Robotika Universitas Diponegoro.

Setelah dilakukan pengujian, didapatkan hasil sebagai berikut :

Pengujian ini dilakukan sebanyak 42 kali dengan mengirimkan perintah ke sistem dengan parameter = lama waktu respon perilaku sistem setelah menerima pesan dari 
pengguna dan parameter $=$ respon sistem membalas pesan pengguna setelah perilaku sistem terpenuhi.

Berikut rata-rata waktu respon perilaku sistem $=$

$\frac{\text { Jumlah Waktu Respon Perilaku Sistem }}{42}=\frac{480,3}{42}=11,4$ detik

Rata-rata Waktu Respon SMS =

$\frac{\text { Jumlah Waktu Respon SMS }}{42}=\frac{890,1}{42}=21,2$ detik

Setelah dilakukan pengujian yang pertama, dan hasil sudah didapatkan, selanjutnya yaitu pengujian mengirimkan pesan singkat ke sistem untuk melihat kondisi status ataupun info, pengujian dilakukan sebanyak 24 kali. Berikut rata-rata waktu respon SMS =

$\frac{\text { Jumlah Waktu Respon SMS }}{24}=\frac{512,7}{24}=21,3$ detik

\section{Pengujian Perintah di Luar Sistem}

Pengujian ini akan membuktikan bahwa di luar perintah yang sudah ditentukan oleh sistem, dimana situasi ketika pengguna sengaja ataupun tidak sengaja melakukan kesalahan dalam mengirim perintah. Sistem akan membalas bahwa perintah tersebut tidak ditemukan dalam sistem. Pada Gambar 9 dan Gambar 10 menunjukkan reaksi sistem ketika ada pesan yang tidak sesuai.

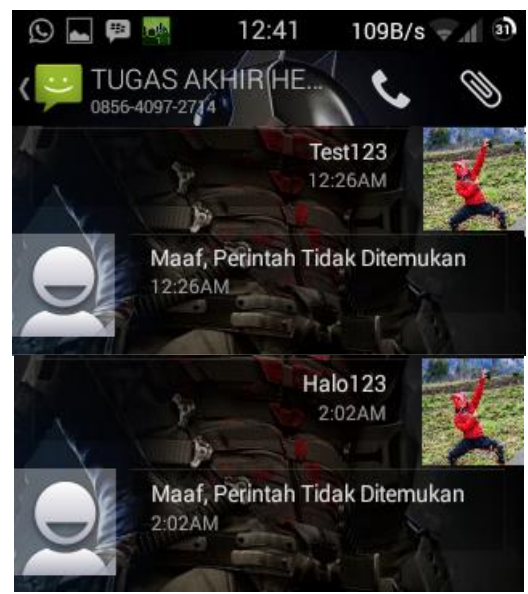

Gambar 9 Perintah "Maaf, Perintah Tidak Ditemukan"

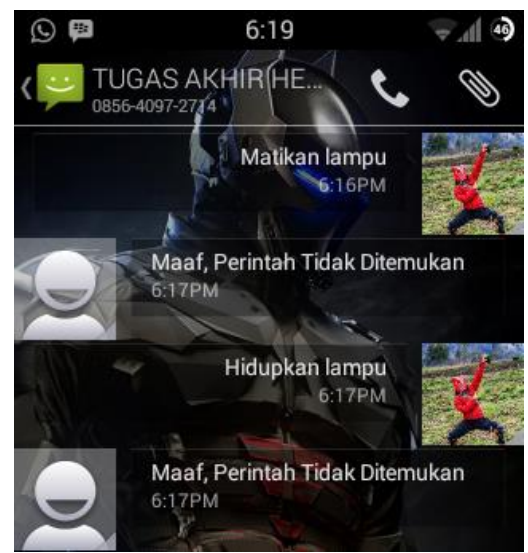

Gambar 10 Perintah "Maaf, Perintah Tidak Ditemukan"
9. Pengujian Identifikasi Nomer Telepon

Pengujian dilakukan menggunakan 3 buah perangkat ponsel pintar, salah satu dari 3 buah ponsel pintar tersebut sudah terindentifikasi oleh sistem. Pengujian ini akan membuktikan bahwa selain nomor yang sudah teridentifikasi sistem tidak akan bisa menerima perintah apapun dan ketika nomor lain mencoba mengirim pesan ke sistem, sistem akan otomatis akan menghubungi pengguna yang telah teridentifikasi nomor teleponnya bahwa nomor "085xxxxxx" mencoba masuk.

Ketiga ponsel dengan nomor telepon berbeda beda mengirim pesan dengan perintah "info" secara bersamaan, pada ponsel yang nomor teleponnya sudah teridentifikasi oleh sistem akan mendapat balasan pesan dari sistem kemudian pada dua ponsel yang nomernya tidak teridentifikasi oleh sistem tidak mendapat balasan dari sistem, namun muncul notifikasi pada ponsel yang nomornya teridentifikasi oleh sistem yaitu kedua ponsel yang nomornya tidak teridentifikasi mencoba masuk.

\section{PENUTUP}

Dari hasil pengujian dan analisis perancangan sistem kendali pada alat listrik rumah tangga menggunakan media pesan singkat (SMS), alat dapat menyalakan dan dapat mematikan terminal yang terhubung dengan alat listrik menggunakan perintah SMS sekaligus dapat mendeteksi keberadaan panas tubuh manusia di dalam suatu ruangan, selain menyalakan dan mematikan alat juga dapat menerima perintah untuk mode aman dan mode hemat sesuai dengan kebutuhan pengguna. Pesan yang dikirim dari pengguna ke sistem harus sesuai dengan perintah yang sudah ditentukan oleh sistem, namun jika sewaktu-waktu pengguna mengirimkan pesan yang salah ke sistem, sistem akan membalas dengan isi pesan "Maaf, Perintah Tidak Ditemukan". Untuk sistem keamanan dari alat, jika ada nomor di luar atau belum diidentifikasi sistem mencoba masuk ataupun mencoba mengirimkan pesan ke sistem, sistem akan memberikan notifikasi ke pengguna yang nomernya sudah diidentifikasi bahwa ada nomer asing mencoba masuk ke dalam sistem.

Berdasarkan pengujian dan analisa sistem, sistem masih memerlukan penyempurnaan, Alat ini masih bisa dikembangkan dari sisi desain maupun komponen yang digunakan, Sebagai contoh penggunaan komponen seperti LCD untuk mempermudah interface antara pengguna dengan sistem. Perlu penambahan fitur untuk memberi notifikasi jika pulsa yang digunakan dalam alat habis dan fitur untuk menghitung penggunaan daya listrik. Penambahan fitur bluetooth atau wireless untuk menyalakan dan mematikan terminal sebagai alternatif pengganti pesan singkat (SMS). Perlu pembuatan aplikasi untuk perangkat bergerak supaya tampilan terlihat lebih menarik 


\section{UCAPAN TERIMA KASIH}

Terima kasih disampaikan kepada Bapak Rizal Isnanto dan Eko Didik Widianto atas segala bimbingan dan masukan terhadap penelitian yang telah diberikan, serta seluruh civitas akademik Program Studi Sistem Komputer Undip yang telah memberikan berbagai ilmu yang bermanfaat.

\section{DAFTAR PUSTAKA}

[1] Evans, Bryan. (2011). Beginning Arduino Programming. New York : Apress.

[2] Melalolin, Ivan. (2007). Rancang Bangun Brankas Pengaman Otomatis Berbasis Mikrokontroler AT89S52. Bandung : Fakultas Teknik Unikom.

[3] Daryanyo, Fauzi. (2012). Monitoring Lampu Koridor Gedung A D4 Pens-ITS dengan Menggunakan Wireless Sensor Network (WSN). Institut Teknologi Sepuluh November, Surabaya.
[4] Budiharto, Widodo. (2011). Aneka Proyek Mikrokontroler, Panduan Utama untuk Riset/TA. Yogyakarta : Graha Ilmu.

[5] Pressman, R.S. (2010), Software Engineering : a practitioner's approach, McGraw-Hill : New York.

[6] Scaddan, Brian. (2003), Electric Wiring Domestic Twelfth Edition. Elsevier Ltd : England.

[7] Sutarmanto, Nanang. (2007), Sistem Kendali Perangkat Listrik Menggunakan Media SMS (Short Message Service). Universitas Sebelas Maret, Surakarta.

[8] Baaret, S.F. (2013). Arduino Microcontroller Processing for Everyone ! Third Edition. A Publication in the Morgan and Claypool Publishers series.

[9] Banzi, Massimo. (2008). Getting Started With Arduino. USA : O’Reilly Media, Inc.

[10] Kadir, Abdul. (2012). Panduan Praktis Mempelajari Aplikasi Mikrokontroler dan Pemrogramannya Menggunakan Arduino. Yogyakarta : Andi. 